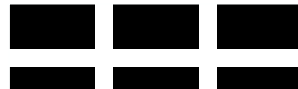 \\ THE WILLIAM DAVIDSON INSTITUTE AT THE UNIVERSITY OF MICHIGAN
}

\section{Regional Determinants of FDI Distribution in Poland}

\author{
By: Agnieszka Chidlow and Stephen Young
}

William Davidson Institute Working Paper Number 943

November 2008 


\title{
Regional Determinants of FDI Distribution in Poland
}

\author{
Agnieszka Chidlow* and Stephen Young**
}

Abstract

In this paper we examine the location determinants of the inflow of Foreign Direct Investment (FDI) into Poland, at a regional level. Using survey data from an online questionnaire in February 2005 and a multinomial logit model incorporating the investor's specific characteristics, we show that knowledge-seeking factors alongside market and agglomeration factors, act as the main drivers for the inflow of FDI to the Mazowieckie region (including Warsaw), while efficiency and geographical factors encourage FDI to the other areas of Poland. Some implications are drawn for FDI attraction policy in Poland.

JEL classification:F23; L20; R10

Keywords: location choice, transition economies, foreign direct investment

\section{Introduction}

Following the collapse of communism, the countries of Central and Eastern Europe (CEE), have been forging strategies to attract foreign capital as a way of achieving sustained economic growth (Martin and Velăzquez, 2000). Foreign direct investment by multinational corporations (MNCs) plays an important role in the transformation of former centrally planned economies into vibrant market systems, since it provides an inflow of capital, management skills, and jobs, alongside increasing exports and transfer of technology. It is also perceived as one of the conditions paving the way for improving the competitiveness of the economy and enhancing the provision of goods and services for the domestic market.

\footnotetext{
*Faculty of Business and Law, Staffordshire University, Stoke-on-Trent, ST4 2DF, UK.

E-mail<a.chidlow@staffs.ac.uk>

** School of Business and Management, University of Glasgow, Glasgow, G12 8QQ, UK.

E-mail<s.young@mgt.gla.ac.uk>

Correspondence: Agnieszka Chidlow, Staffordshire University, Faculty of Business and Law, Leek Road, Stoke-onTrent, ST4 2DF, UK, Fax: (01782) 294907.
} 
With the implementation of global and regional strategies by MNCs, the choice of location is becoming increasingly important, hence requiring a better understanding of the internationalization process and of the factors influencing the spatial distribution of FDI.

There have been numerous empirical studies that have focused on the location choices of MNCs and FDI flows in developed countries (Shaver, 1998; Head et al., 1995; Friedman et al., 1992; Culem, 1988; Nachum and Wymbs, 2005) ${ }^{1}$. Since early-2000s these studies have also started to concentrate on the transition economies within the CEE region (Campos and Kinoshita, 2003; Deichmann, 2001; Resmini, 2003, 2007; Boudier-Bensebaa, 2005; Cieślik and Ryan, 2005). According to Slay $(2003$, p.1) "... relative to the rest of the world, this region has been an excellent bet".

Despite the growing interest in the subject, to our knowledge, there is still no satisfactory empirical work which can explain the determinants of the spatial distribution of FDI flows into the separate regions of Poland ${ }^{2}$, the largest new EU-member state. Thus, this research attempts to fill this gap by using a primary data from an on-line questionnaire that covers the entire transition period.

Following the administrative decentralization introduced by the government in January 1999, a new territorial organization of Poland was introduced. The system replaced 49 voivodships with just 16 (Figure 1). The new structure of sizeable regions with their statutory combination of central government and self-government functions was created in order to achieve more effective regional policies. This was based on the assumption that by decreasing the number of voivodships, the disparities at the level of territorial division among them can be reduced (Czyż, 2002). As claimed by Górzelak (2002) in the old system a steady and comparatively high growth rate was only recorded in big metropolitan regions such as Warsaw and Poznań, while the remaining regions registered a decline in their economic situation to a greater or lesser degree. The establishment of bigger voivodships with new territorial shapes have been a crucial step in Poland's adjustment to EU regulations (Churski, 2005).

\footnotetext{
${ }^{1}$ For a summary of recent research on location choices of FDI in developed countries see Boudier-Bensebaa (2005).

2 Altomonte and Resmini (2001) investigate whether MNCs generate backward and forward linkages with domestic firms given their regional location in Poland rather than the determinants of FDI.
} 
Figure 1. The new territorial system of Poland in comparison with the old one

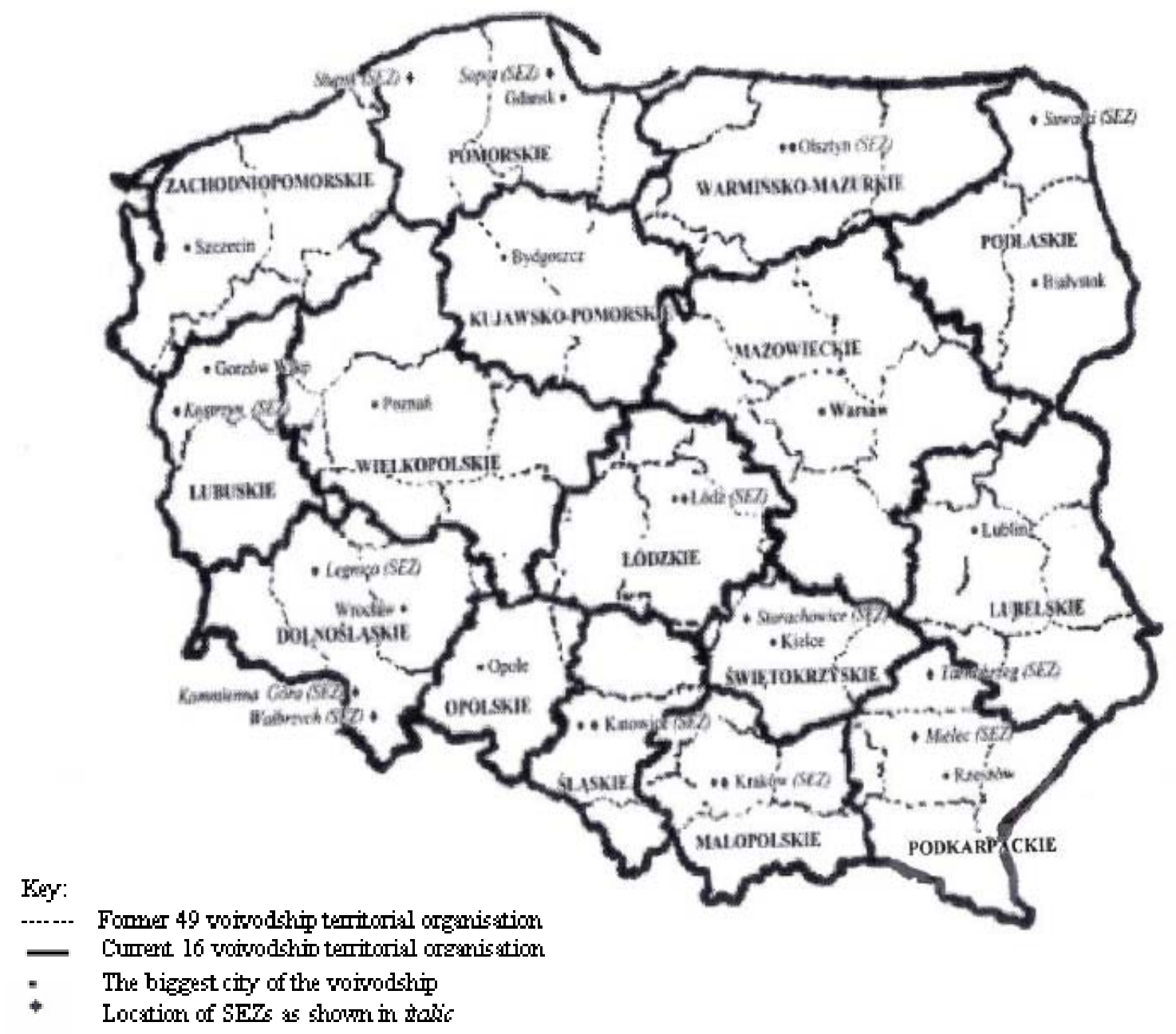

Despite the new decentralized territorial system of Polish regions, the quality and allocation of FDI into those regions is still uneven. For example, the areas in the west, north, south and center of Poland, are the most prosperous and have been the most successful in attracting foreign capital, while the districts further to the east continue to suffer from lower investment, lower income and higher unemployment (The Economist Intelligence Unit, 2004).

Based on a regional-level dataset obtained from an on-line questionnaire conducted in February 2005, this paper provides an empirical contribution in two ways. First, it addresses the motives for the initial inflow of foreign capital into a particular Polish region. Second, it presents an investor's individual dataset at a regional level for Poland - both the largest recipient of FDI in CEECs and the largest country of the new EU members. 
The remainder of the paper is structured as follows. Section one presents the underlying streams of literature and hypothesis formulation. Section two explains the method of data collection, the specification of the model and the variables used. Section three presents the econometric results that are then discussed. The conclusions and policy implications are finally presented in section four.

\section{Section 1. Underlying literature and hypothesis formulation}

It has been recognized by scholars that different motives lie behind the investment decisions of firms in foreign countries. It is argued that "...there are substantial differences in economic performance across regions in virtually every nation. This suggests that many of the essential determinants of economic performance are to be found at the regional level" (Porter, 2003, p.550). In order to examine the rationale in one of the transitional economies, the theoretical framework of this paper addresses three branches of the literature.

The first branch emphasizes the new economic geography (NEG) initiated by Krugman (1991a, 1993, 1995) and later synthesized by Fujita et al., (1999) which according to Brakman and Garretsen (2003) "... is the only theory within mainstream economics that takes the economics of location seriously..." (p. 638). Drawing upon Marshall (1920), Krugman proposes a model where the trade-off between increasing returns in production and transportation costs is fundamental to the understanding of agglomeration economies and the emergence of the centre-periphery pattern. In contrast to location theory (Weber, 1909; Lösch, 1940), Krugman's model insists on full generalequilibrium conditions where the spatial structure emerges from imperfect competition. Krugman $(1996,1998)$ also demonstrates that the location of economic activity is determined by two groups of factors. First, those that include traditional natural advantages of particular locations such as central location, market size, and external economies that relate to supply linkages or others such as knowledge spillovers. Second, those that consist of market forces including all kinds of input costs and non-market factors such as pollution.

While all the above forces play some role in the choice of location, empirical studies suggest that their importance may vary depending on a region, country or industry. For example, Levinson (1996) and Coughlin and Segev (2000), analysing the establishment of new plants in US, show that agglomeration is the principal motive for the explanation of the attractiveness of the South-East region for new plants. Barrios et al., (2002), looking at the location choice of MNCs in Ireland, find that agglomeration forces contribute substantially to location choices as well as the proximity to 
major ports and airports. Disdier and Mayer (2004) find that agglomerations effects are key location determinants of French investment in Western and Eastern Europe. In respect of transition economies, Campos and Kinoshita (2003) and Pusterla and Resmini (2005) find that agglomerations are one of the principal determinants of the spatial distribution of FDI. Martin and Velăzquez, (2000) find a significantly negative effect of distance on FDI in the OECD countries, and a positive significant effect if the host and source countries share a common border. Drawing on the above empirical literature which states that geographical proximity and agglomeration positively encourage the inflow of FDI, we establish our first two hypotheses as follows:

Hypothesis 1: Agglomeration factors are a significant motive for MNC internationalization: hence the stronger agglomeration factors are represented in a given region, the more likely a $\mathrm{MNC}$ will engage in inward FDI in that region.

Hypothesis 2: Geographical factors are an important motive for MNC internationalization: hence the stronger geographical factors are represented in a given region, the more likely a $\mathrm{MNC}$ will engage in inward FDI in that region.

The second branch of the literature derives from the knowledge-based view of the firm (Cantwell, 1989; Cantwell and Janne, 1999; Cantwell and Piscitello, 2002, 2005). Cantwell (1989) states that knowledge-seeking investments vary across locations because they depend on locationspecific factors, such as the number of scientists and educated people in the area, previously established innovations, R\&D intensity, the education system, and good linkages between educational institutions and firms. As a result, firms may supplement their existing technologies by expanding internationally to access new knowledge. This expansion may suggest two types of knowledge-seeking behavior between firms originating from leading versus lagging technical centers (Cantwell and Janne, 1999). Firms from lagging technical locations need to catch up and locate their research centers abroad in order to improve their existing technology. However, while firms from leading locations do not need to catch up, they may also locate their research centers abroad to source more diverse knowledge, since "... the acquisition of new skills, and the generation of new technological capacity, partially embodied in new plant and equipment, must be a goal of every firm" (Cantwell, 1989, p.8). Due to the fact that knowledge is partially tacit and its transfer needs frequent interactions, knowledge-seeking investment requires physical proximity (Kogut and Zander, 1992). Moreover, efforts to search for knowledge-seeking investment are not carried out in 
isolation, but are strongly supported by various external organizations such as, for example, public research centers, universities or industry associations (Cantwell and Piscitello, 2005). The educational level of a country's citizens, alongside the existence of universities, research centers, science bases and other institutions that create knowledge in a region, has become increasingly important for the internationalization process, not only at the national level but also at the regional level (Cantwell and Iammarino, 2001, 2005; Acs et al., 2002; Chung and Alcácer, 2002). Kuemmerle (1999) shows empirically that firms in technology-intensive industries by establishing R\&D facilities abroad can expand their technological capabilities. Florida (1997) finds that accessing new indigenous technology is more important than customizing existing technology for new markets. Bartlett and Ghoshal (1999) show that as firms establish their facilities abroad and allocate heterogenous products to them, R\&D sites in close proximity to factories are needed. This is due to the fact that these sites support the transfer of knowledge, which is an attractive factor for the location of multinational companies (Cantwell and Piscitello, 2002). In addition, specific regions within nations might be particularly attractive locations for knowledge-seeking investment (Jensen, 2004). Acknowledging the fact that there is insufficient empirical evidence relating to the importance of knowledge-seeking motives in the spatial distribution of FDI at a regional level (Cantwell and Piscitello, 2005; Cantwell and Iammarino, 2003) we present our next hypothesis:

Hypothesis 3: Knowledge-seeking factors are a central motive for MNC internationalization: hence the stronger knowledge factors are represented in a given region, the more likely a $\mathrm{MNC}$ will engage in inward FDI in that region.

The last branch addresses the literature on the determinants of FDI in transition economies (Lansbury et al., 1996a; Holland and Pain, 1998; Mayer, 2001; Estrin et al., 2001; Rasmini, 2000; Lankes and Venables, 1996; Garibaldi et al., 2001; Brenton et al., 1999; Cieślik and Ryan, 2005). For instance, Garibaldi et al., (2001) find that the pattern of inward direct investment in transition economies can be well explained in terms of a standard set of economic fundamentals such as those reflecting macroeconomic stability, the level of economic reforms, trade liberalization, natural resource endowments and the privatization method. Lansbury et al., (1996a) demonstrate that labour costs and research intensity have a significant influence on the pattern of inward investment. The evidence is consistent with the notion that some investors have been attracted to CEECs by a combination of relatively low labour costs and the availability of skilled workers in particular 
sectors and countries. Holland and Pain (1998) support and extend the findings of Lansbury et al., (1996a) by showing that the extent of trade linkages with the advanced economies and proximity to the EU have significant effects on the level of investment. The availability of low cost production inputs are traditionally the most obvious reasons for setting up production facilities in foreign countries (Dunning, 1983, 1993a). Estrin et al., (2001) find that the search for resources is an important determinant of FDI inflows in Eastern European countries and Galego et al., (2004) confirmed these results for CEECs. Przybylska and Malina (2000) and Ghemawat and Kennedy (1999) find that market-seeking positively influence FDI flows to Poland. For this reason, it is possible to hypothesize a positive relationship between resource-seeking investment and the regional location of FDI. Following on from this, our final two hypotheses state:

Hypothesis 4: Market-seeking factors are a significant motive for MNC internationalization: hence the stronger market factors are represented in a given region, the more likely a MNC will engage in inward FDI in that region.

Hypothesis 5: Efficiency-seeking factors are a valuable motive for MNC internationalization: hence the stronger efficiency-seeking factors are represented in a given region, the more likely a MNC will engage in inward FDI in that region.

\section{Section 2. The dataset description and methodology}

\subsection{Data collection}

The data for the present study derives from an on-line questionnaire, which was designed to examine the locational determinants of FDI in the Polish regions. The data collection was undertaken in February 2005. The list of 1243 MNCs was obtained from Polish Information and Foreign Investment Agency (PAIIIZ) and it included names and addresses of foreign companies that have already established their presence on the Polish market, in the form of FDI, before 2003.

Due to the fact that the given data set was two years old, we examined its validity by checking the contact details of each investor using the internet and phone. We found that 147 companies were no longer reachable and 96 were double-counted. In addition, 148 companies were used for the pilot study. Hence, this left us with 852 companies in the dataset for the final analysis.

The final questionnaire was developed following a pilot study conducted in November 2004 in order to make sure that the questions of the questionnaire were clear to understand and follow by participants. Following Dillman (2000), a sample of 148 randomly selected respondents was drawn 
for the pilot. $65 \%$ of participants in the pilot study were of European origin and 35\% non-European; the response rate was $8.5 \%$. Judging by the response rate it was clear that a self-administered electronic survey would be an appropriate technique for this study (Kanuk and Berenson, 1975).

The structure of the final questionnaire covered topics ranging from general information about the MNC (e.g. year of establishment, origins, employment, sales and turnover) to specific information about the Polish location (e.g. entry mode, region, motive for investing) and characteristics relating to the post-entry development of the Polish subsidiary (e.g. competition, future plans).

In order to encourage participation in the survey, a system of four compatible contacts, using the internet, were established with potential respondents (Dillman, 2000; Heberlein and Baumgartner, 1978). First, a brief prenotice e-mail was sent out to the senior management of all the companies for which the contact details had been verified, prior to sending the questionnaire. The aim of the letter was to explain the objectives and importance of the study, and to request their participation in it. Second, a link to the on-line questionnaire was sent out to the respondents who had expressed interest in participating in the study. It is worth noting that 237 contact e-mails were deleted by the respondents before they were even read. So, 615 contacts read the initial e-mail. 195 e-mail responses were received with the note "will not participate in the study". 329 contacts did not respond at all. As a result, the number of respondents amounted to 91, representing approximately $15 \%$ of those initially contacted (see Appendix for some sample characteristics). Third, a reminder letter was sent out one week after the link to the questionnaire was delivered. The purpose of this letter was to express appreciation for willingness to fill out the questionnaire, and at the same time to indicate that if the respondent has not yet completed the questionnaire to encourage response. Finally, a thank you letter was sent to all respondents after the collection of the results.

The regional data, for this investigation, is in line with the Nomenclature of Territorial Unites for Statistics (NUTS) ${ }^{3}$ level 2. However, after its the examination foreign firms were grouped in five regions (Figure 2 in Appendix): North-West (28\% of the firms in the sample) including the Zachodnio-pomorskie, Pomorskie, Lubuskie and Wielkopolskie voivodships; North-East (11\%) containing the Warmińsko-mazurskie, Podlaskie and Kujawsko-pomorskie voivodships; the Mazowieckie voivodship (25\%) containing Warsaw, the capital; South-East $(11 \%)$ including the

\footnotetext{
${ }^{3}$ The NUTS classification was adopted on May 2003 by the European Parliament and the Council of the European Union in order to manage changes on the availability and comparability of regional statistics of Member States.
} 
Lubelskie, Podkarpackie, Świętokrzyskie and Małopolskie voivodships; and South-West (25\%) containing the Łódzkie, Dolnośląskie, Śląskie and Opolskie voivodships. This classification represents NUTS-1 level.

The regional breakdown was based on a small village, Piątek (i.e. Friday) in the Łódzkie voivodship, which represents the geographical middle point of Poland and Europe as well (Kondracki, 1994). This separation was done for two reasons. First, "...from a methodological point of view categories (such as regions) should include a minimum number of cases in order to conduct a meaningful statistical analysis..." (Oerlemans and Meeus, 2005, p.96). This is important in our case, because the spatial level among 16 Polish regions was uneven in the sample. Second, several notable structural economic differences can be seen between those five regions in Table 1. 
Total area $\left(\text { in } \mathrm{km}^{2}\right)^{1}$

- of which towns

- of which villages

Population (in million) ${ }^{1}$

Employment (in thousands) $)^{1,2}$

Unemployment rate (in \%)

$\mathrm{GDP}^{3}$

Gross Domestic Expenditure on $\mathrm{R} \& \mathrm{D}^{3}$

Researchers employed in $R \& D^{4}$

Graduates of higher education

(in thousands)

Hard surface public roads ${ }^{1,5}$

Railway lines ${ }^{1,5}$

Telephone line (per1000 population) ${ }^{1}$

Budget of voivodship - expenditure

\begin{tabular}{|c|c|c|c|c|c|c|c|}
\hline \multicolumn{4}{|c|}{ North - West } & \multicolumn{3}{|c|}{ North -East } & Mazowieckie \\
\hline $\begin{array}{l}\text { Zachodnio- } \\
\text { pomorskie }\end{array}$ & Pomorskie & Lubuskie & Wielkopolskie & $\begin{array}{l}\text { Kujawsko- } \\
\text { pomorskie }\end{array}$ & $\begin{array}{l}\text { Warmińsko- } \\
\text { mazurskie }\end{array}$ & Podlaskie & Warsaw \\
\hline 22.9 & 18.3 & 13.9 & 29.8 & 17.9 & 24.2 & 20.2 & 35.6 \\
\hline 61 & 42 & 42 & 109 & 52 & 49 & 36 & 84 \\
\hline 3172 & 2994 & 1508 & 5504 & 3581 & 3865 & 3945 & 9084 \\
\hline 1.7 & 21.8 & 1.0 & 3.4 & 2.1 & 1.4 & 1.2 & 5.1 \\
\hline 513.4 & 698.8 & 304.2 & 1296.1 & 713.9 & 429.8 & 478.7 & 2275.8 \\
\hline 26.4 & 21.2 & 26.0 & 16.1 & 22.5 & 28.8 & 15.2 & 13.9 \\
\hline 33423.9 & 42498.7 & 17675.8 & 69397.1 & 36884.7 & 20659.8 & 17976.2 & 153702.2 \\
\hline 90.6 & 227.2 & 138.5 & 324.7 & 110.4 & 56.4 & 38.0 & 1994.3 \\
\hline 2.1 & 5.5 & 2.2 & 2.7 & 2.2 & 1.5 & 1.4 & 7.3 \\
\hline 19,4 & 16,0 & 6,4 & 28,2 & 16,6 & 10,4 & 10,8 & 72,7 \\
\hline 56,8 & 62,3 & 55,9 & 88,6 & 77,9 & 53,5 & 53,5 & 72,5 \\
\hline 5,6 & 7,6 & 6,5 & 6,8 & 7,1 & 5,5 & 3,9 & 4,8 \\
\hline 325,5 & 302 & 322,2 & 259,7 & 298,5 & 310,4 & 356,6 & 359,1 \\
\hline 200,7 & 249,8 & 172,1 & 389,4 & 237,5 & 168,3 & 146,8 & 494,3 \\
\hline
\end{tabular}

(in million zlotys)

${ }^{1}$ As of 31. 12. 2002.

${ }^{2}$ In percentage of the national average.

${ }^{3}$ In current prices. GUS (2003).

${ }^{4}$ Employed full time; per 1000 economically active persons.

${ }^{5}$ Per $100 \mathrm{~km}^{2}$ of total area in $\mathrm{km}$

Source: GUS (2003, 2004); PAIiIZ (2003, 2004) and authors' own calculations. 
Table 1. Characteristics of Polish regions (continued)

\begin{tabular}{|c|c|c|c|c|c|c|c|c|}
\hline \multirow[b]{3}{*}{ Total area $\left(\mathrm{in} / \mathrm{km}^{2}\right)^{1}$} & \multicolumn{4}{|c|}{ South - West } & \multicolumn{4}{|c|}{ South - East } \\
\hline & Łódźkie & Dolnoślaskie & Opolskie & Ślaskie & Lubelskie & Podkarpackie & Świętokrzyskie & Mtopolskie \\
\hline & 18.2 & 19.9 & 9.4 & 12.3 & 25.1 & 17.9 & 11.7 & 15.1 \\
\hline - of which towns & 42 & 90 & 34 & 71 & 41 & 45 & 30 & 55 \\
\hline - of which villages & 5167 & 2903 & 1555 & 1511 & 4173 & 2163 & 2831 & 2631 \\
\hline Population (in million) ${ }^{1}$ & 2.6 & 2.9 & 1.1 & 4.7 & 2.2 & 2.1 & 1.3 & 3.2 \\
\hline Employment (in thousands) ${ }^{1,2}$ & 1017.5 & 950.1 & 342.3 & 1647.3 & 947.7 & 916.7 & 570.4 & 1278.8 \\
\hline Unemployment rate $(\text { in } \%)^{1}$ & 18.4 & 22.4 & 19.3 & 16.5 & 15.7 & 16.9 & 18.5 & 13.9 \\
\hline $\mathrm{GDP}^{3}$ & 33423.9 & 42498.7 & 17675.8 & 69397.1 & 36884.7 & 20659.8 & 17976.2 & 153702.2 \\
\hline Gross Domestic Expenditure on $\mathrm{R} \& \mathrm{D}^{3}$ & 298.6 & 276.5 & 30.2 & 342.5 & 25.2 & 119.0 & 14.1 & 496.5 \\
\hline Researchers employed in $R \& D^{4}$ & 2.2 & 3.7 & 3.0 & 4.1 & 2.6 & 1.1 & 1.1 & 5.5 \\
\hline $\begin{array}{l}\text { Graduates of higher education } \\
\text { (in thousands) }\end{array}$ & 20,8 & 26,9 & 7,9 & 37,9 & 18,2 & 15,4 & 14,3 & 25,6 \\
\hline Hard surface public roads ${ }^{1,5}$ & 88,3 & 92,2 & 87,7 & 163 & 71,2 & 78,6 & 95,8 & 144,0 \\
\hline Railway lines ${ }^{1,5}$ & 6,0 & 9,3 & 9,3 & 18,9 & 4,2 & 5,3 & 6,2 & 7,7 \\
\hline Telephone line (per1000 population $)^{1}$ & 316,2 & 351,5 & 250,7 & 318,4 & 353,6 & 215,0 & 237,9 & 291,4 \\
\hline $\begin{array}{l}\text { Budget of voivodship - expenditure } \\
\text { (in million zlotys) }\end{array}$ & 223,4 & 320,1 & 112,7 & 605,1 & 244,4 & 242,0 & 162,1 & 365,0 \\
\hline
\end{tabular}

\section{${ }^{1}$ As of 31. 12.2002.}

${ }^{2}$ In percentage of the national average.

${ }^{3}$ In current prices. General Statistical Office (2003).

${ }^{4}$ Employed full time; per 1000 economically active persons.

${ }^{5}$ Per $100 \mathrm{~km}^{2}$ of total area in $\mathrm{km}$

Source: General Statistical Office $(2003,2004)$; PAIiIZ $(2003,2004)$ and authors' own calculations. 


\subsection{A model of a choice region}

Following Levinson (1996), Louri et al., (2000) and Crozet et al., (2002) we assume that foreign investors have a latent (i.e. unobserved) profit function once they have decided to establish their physical presence, for the first time, in one of the Polish regions. The profit function is dependent on the characteristics of the individual investor, and the random component that is arising from other unobserved characteristics of choices. Thus, the utility function of locating in region $j$ for the $n$-th investor faced with $J$ choices of regions can be written in the following form:

$$
U_{\mathrm{nj}}=\mathrm{x}_{\mathrm{n}} \beta_{\mathrm{j}}+\varepsilon_{\mathrm{nj}}
$$

where there are $J$ error terms $\varepsilon_{\mathrm{nj}}$ for any investor $n$. The exogenous variables $x_{\mathrm{n}}$ describe only the investor and are identical across alternatives. However, the parameter $\beta_{\mathrm{j}}$ differs across alternatives.

If the investor chooses region $j$ in particular, then we assume that $U_{\mathrm{nj}}$ is the maximum among the $J$ utilities. Hence, the statistical model is driven by the probability that region $j$ is chosen, which is

$$
\operatorname{Pr}\left(U_{\mathrm{nj}}>U_{\mathrm{nk}}\right) \text { for all other } k \neq j
$$

Assuming that the error terms in Eq. (1) follow independently and identically an extreme value distribution $^{4}$ (Manski and Lerman, 1977; McFadden, 1984; Maddala, 1977) of the following form:

$$
\mathrm{F}\left(\varepsilon_{\mathrm{nj}}\right)=\exp \left(-\mathrm{e}^{-\varepsilon_{\mathrm{nj}}}\right) .
$$

the probability that an investor $n$ chooses region $j$ is a simple expression of

$$
\operatorname{Pr}_{n j}=\operatorname{Pr}\left(Y_{n}=j \mid x_{n}\right)=\frac{e^{x_{n}^{\prime} \beta_{j}}}{\sum_{i=1}^{J} e^{x_{n}^{\prime} \beta_{j}}},
$$

Eq. (4) forms the basis for the multinomial logit model (MNLM) (Greene, 2002). An interesting feature of this model is that the odds ratio $\left(\mathrm{Pr}_{\mathrm{nj}} / \mathrm{Pr}_{\mathrm{ni}}\right)$ depends log-linearly on $x_{\mathrm{n}}$. Hence $J \log$-odds ratios can be computed based on:

\footnotetext{
${ }^{4}$ Also known as a Weibull distribution
} 


$$
\ln \Omega_{\mathrm{j} \mid \mathrm{i}}\left(x_{n}^{\prime}\right)=\ln \left[\frac{\operatorname{Pr}\left(y=j \mid \mathrm{x}_{\mathrm{n}}^{\prime}\right)}{\operatorname{Pr}\left(y=i \mid \mathrm{x}_{\mathrm{n}}^{\prime}\right)}\right]=\mathrm{x}_{\mathrm{n}}^{\prime} \beta_{j \mid i} \quad \text { for } \quad j=1, \ldots, J
$$

where $i$ is the base category. As $\ln \Omega_{\mathrm{m}} \mathrm{i}\left(\mathrm{x}^{\prime}{ }_{\mathrm{n}}\right)=\ln 1=0$, it must be hold that $\beta_{\mathrm{i}} \mathrm{i}=0$. That is, the $\log$ odds of an outcome compared with itself are always 0 , and thus the effects of an independent variable must also be 0 . Hence we will only estimate $J-1$ outcomes, due to the redundant information (Long and Freese, 2003).

The independence of the error term across alternatives in Eq. (1) is a strong assumption, and it implies that an investor's unobserved preference for a certain alternative is independent of its stochastic preference for other alternatives. This imposes the independence of irrelevant alternatives (IIA) restriction on the predicted probabilities, which means that the choice of the regions must be equally substitutable to investors (Hausman and McFadden, 1984).

The results are discussed in Section 3.

\subsection{Dependent variable}

Our dependent variable represents the probability of either investing or not in any given region mentioned above, with the Mazowieckie region being the comparison group. There are three reasons for selecting this particular region as the base category. First, the region includes Warsaw, the capital and at the same time the largest city in the country with its population of 1.6 million people (General Statistical Office, 2004). Second, this is the leading area for finance, real estate and business services. Finally, it has benefited most from the transition to a market economy, consistently reporting the highest average income, lowest unemployment and largest share of inward investment of any Polish voivodship (The Economist Intelligence Unit, 2003).

\subsection{Independent variables}

In line with our theoretical discussion, thirteen motives measuring the importance of investing in a given Polish region, were extracted from the literature for the study. They formed a separate question in the questionnaire with the heading: What were the reasons to invest in that particular voivodship? The question was close-ended where, following Willits and Saltiel (1995), the degrees 
of importance were based upon a six-point scale ranged from "not sure" (coded 0) ) $^{5}$ "extremely important" (coded 5). Based on the underlying literature the motives were then classified into five groups of explanatory variables. In order to examine the inter-relationship and confirm both the relevance and significance of those variables for the analysis, a confirmatory factor analysis was performed (Table 2).

\footnotetext{
${ }^{5}$ By using a 6-point scale with the option "not sure", the researcher can allow respondents a way out of answering a question, when he or she feels threatened by admitting that the answer to that question is not important. As a result, the researcher can still quantify the response (Sounders et al., 2000; Willits and Saltiel, 1995).
} 


\section{Geographical factors}

1) Lower transportation costs (e.g. shipping) $\quad 0.79308$

2) Geographic conditions favourable for physical distribution (i.e. $\quad 0.82489$ geographical distance)

3) Good quality of local infrastructure

0.74006

(i.e. the quality and availability of roads and highways)

\section{Agglomeration factors}

1) Supporting industries already exist for supply of parts and components

2) A number of other companies from the same country were already operating there

3) A number of other companies in the same industry were already operating there

\section{Efficiency-seeking factors}
1) Availability of labour
2) Low labour cost
3) Availability of raw materials at low cost

"fdistance
0.79308
0.82489
0.74006

\section{Knowledge-seeking factors}

1) Educational level in the region (e.g. foreign languages)

2) Local universities and research centers

0.60849

0.69263

0.82432

\section{Market-seeking factors}

1) Economies of scale

2) Consumers' demand

\begin{tabular}{|c|c|c|c|c|c|}
\hline 2) Comsunters deninand & & & & & 0.77205 \\
\hline Observations No. & 91 & 91 & 91 & 91 & 91 \\
\hline Eigenvalue & 1.85710 & 1.52951 & 1.58763 & 1.14794 & 1.19214 \\
\hline Proportion of Variance explained & .6190 & .5098 & .5292 & .5740 & .5961 \\
\hline
\end{tabular}

* After the motives were coded they were grouped into five factors, based on the literature, priori to the confirmatory factor analysis.

** Name of the explanatory variables used in the analysis.

Source: Authors' calculations using Stata 9. 
The factor analysis confirmed the variable structure that we identified. More specifically, we obtained five meaningful factors, according to the criteria for the eigenvalues to be greater than unity (Kim and Mueller, 1978b). For the explanatory variables, we use the extracted factor scores for fdistance, fagglom, fefficien, fwisdom and fmarket (Table 2), as the general measures of the location determinants for the inflow of FDI. The explanatory variables in the model are investor specific. Table 3 (new) shows that multi-collinearity is not present between the motive factors (Gujarati, 2003).

Table 3. Correlation matrix

\begin{tabular}{lccccc|}
\hline & fdistance & fagglom & fefficien & fmarket & fwisdom \\
\hline fdistance & 1.0000 & & & & \\
fagglom & 0.4265 & 1.0000 & & & \\
fefficien & 0.3324 & 0.1893 & 1.0000 & & \\
fmarket & 0.0698 & 0.2018 & -0.1958 & 1.0000 & \\
fwisdom & 0.2148 & 0.1452 & 0.3759 & -0.1826 & 1.0000 \\
\hline \multicolumn{7}{c}{} \\
\hline
\end{tabular}

Source: Authors' own calculations using Stata9.

\subsection{Control variables}

Altomonte (2000) shows that the time dummies have a significant effect on the number of investment undertaken by an MNC in the CEE region. Thus, time dummies were included in the model in order to control for time variation arising from the economic changes common to all CEECs. Pusterla and Resmini (2005) and Resmini (2007) state in their work that sector specific factors affect the choice of final location of MNCs in CEECs. Hence, the dummy variable for the industry in which a specific firm operates (high-tech or low-tech) was also introduced. The classification of manufacturing industries was based on the NACE Rev. 1 codes and is presented in Table 4. 
Table 4. Industry classification, frequencies and percentages.

\begin{tabular}{|c|c|c|c|}
\hline & \multicolumn{3}{|c|}{ INDUSTRY CLASSIFICATION } \\
\hline $\begin{array}{l}\text { HIGH-TECH / } \\
\text { LOW-TECH }\end{array}$ & & FREQ.(\%) & NACE REV.1.1 \\
\hline HIGH-TECH & Radio TV and communication equipment & $4(7.84)$ & 32 \\
\hline HIGH-TECH & Medical precision and optical instruments & $1(1.10)$ & 33 \\
\hline HIGH-TECH & Pharmaceutics & $1(1.10)$ & 24.1 \\
\hline HIGH-TECH & Chemicals (excluding Pharmaceuticals) & $4(4.40)$ & 24 \\
\hline HIGH-TECH & Motor vehicles trailers and semi-trailers & $11(12.07)$ & 34 \\
\hline LOW-TECH & Food products & $4(4.40)$ & 15 \\
\hline LOW-TECH & Tobacco products & $2(2.20)$ & 16 \\
\hline LOW-TECH & Leather products & $2(2.20)$ & 18 \\
\hline LOW-TECH & Paper products & $3(3.30)$ & 21 \\
\hline LOW-TECH & Cole refined petroleum products and nuclear fuel & $2(2.20)$ & 23 \\
\hline LOW-TECH & Rubber and plastic products & $4(4.40)$ & 25 \\
\hline LOW-TECH & Metal products & $1(1.10)$ & 27 \\
\hline LOW-TECH & Other non-metallic products & $8(8.77)$ & 26 \\
\hline LOW-TECH & Furniture products & $2(2.20)$ & 36 \\
\hline LOW-TECH & Recycling & $2(2.20)$ & 37 \\
\hline TOTAL & & $51(56.04)$ & \\
\hline
\end{tabular}

Source: General Statistical Office (2006, 2005) and authors' own calculations.

Using the explanatory and control variables discussed above, the probability of either investing or not in any given region based on Eq. (4) and Eq. (5) of MNLM has the following form:

$$
\begin{aligned}
& \text { choice }_{\mathrm{n}, \mathrm{ji}}=\beta_{0, \mathrm{j} \mathrm{i}}+\beta_{1, \mathrm{j} \mathrm{i}} \text { fdistance }_{n}+\beta_{2, \mathrm{j} \mid \mathrm{i}} \text { fagglom }_{n}+\beta_{3, \mathrm{j} \mathrm{i}} \text { fefficien }_{n} \\
& +\beta_{4, \mathrm{ji}} \text { fwisdom }_{n}+\beta_{5, \mathrm{ji}} \text { fmarket }_{n}+\beta_{6, \mathrm{j} \mid \mathrm{i}} \text { DUM93-96 }_{n}+\beta_{7, \mathrm{j} \mid \mathrm{i}} \text { DUM97-00 } n \\
& +\beta_{8, \mathrm{ji}} \mathrm{DUM} 01-04_{n}+\beta_{9, \mathrm{ji}} \mathrm{DUM}_{n}
\end{aligned}
$$

where $j=1, \ldots 5$ (i.e. 1 for the North-West region, 2 for the North-East region; 3 for the Mazowieckie region; 4 for the South-East region; and 5 for the South-West region); $i=3$ as the comparison category and $n=1, \ldots 91$. The time dummies consider the period from before 1992 to 2004 inclusive, with the exclusion of the period before 1992 in the set of time dummies in order to 
avoid collinearity. The industry dummy represents 1 for high-tech industry and 0 otherwise. Moreover all the explanatory variables in the model are investor's specific. Table 5 summarises the variables used in the model, their measurement and summary statistics.

Table 5. Explanatory variables, their measurement and summary statistics

\begin{tabular}{|c|c|c|}
\hline & \multicolumn{2}{|l|}{ EXPLANATORY VARIABLES } \\
\hline VARIABLES & DEFINITION & MEAN(ST. DEV.) \\
\hline fdistance & Factor score for 1990-2004 (see Table 2) & $-4.77 e-09(1)$ \\
\hline fagglom & Factor score for 1990-2004 (see Table 2) & $8.11 \mathrm{e}-09(1)$ \\
\hline fefficien & Factor score for $1990-2004$ (see Table 2) & $-4.30 \mathrm{e}-09(1)$ \\
\hline fwisdom & Factor score for $1990-2004$ (see Table 2) & $4.58 \mathrm{e}-09(1)$ \\
\hline fmarket & Factor score for 1990-2004 (see Table 2) & $-1.49 \mathrm{e}-08(1)$ \\
\hline DUM93-96 & Dummy: 1 if MNC invested in Poland between 1993-1996; 0 otherwise & $0.407(0.494)$ \\
\hline DUM97-00 & Dummy: 1 if MNC invested in Poland between 1997-2000; 0 otherwise & $0.198(0.401)$ \\
\hline DUM01-04 & Dummy: 1 if MNC invested in Poland between 2001-2004; 0 otherwise & $0.110(0.314)$ \\
\hline DUM $h t$ & Dummy: 1 if MNC invested in high-tech industry; 0 otherwise & $0.4117(0.497)^{*}$ \\
\hline
\end{tabular}

\section{Section 3: Empirical results}

Based on the multinomial logit model with investor's specific characteristics and the variables discussed above, two separate models for the location choice of the inflow of FDI in Polish regions were estimated. The results are presented in Tables 6 and 7. 
Table 6. The choice of Polish region : the multinomial logit model ${ }^{1}$

\begin{tabular}{|c|c|c|}
\hline Choice of a region & Model 1 & Model 2 \\
\hline $\begin{array}{l}\text { 1) } \mathbf{P}_{1} \mid \mathbf{P}_{3} \\
\text { constant }\end{array}$ & $\begin{array}{l}0.806 \\
(0.730)\end{array}$ & $\begin{array}{l}0.929 \\
(0.803)\end{array}$ \\
\hline fdistance & $\begin{array}{l}0.435 \\
(0.484)\end{array}$ & $\begin{array}{l}0.425 \\
(0.824)\end{array}$ \\
\hline fagglom & $\begin{array}{l}-0.734 \\
(0.528)\end{array}$ & $\begin{array}{l}-0.663 \\
(0.792)\end{array}$ \\
\hline fefficien & $\begin{array}{l}2.348^{*} \\
(0.633)\end{array}$ & $\begin{array}{l}2.885^{*} \\
(1.125)\end{array}$ \\
\hline fwisdom & $\begin{array}{l}-1.434^{*} \\
(0.509)\end{array}$ & $\begin{array}{l}-1.883 * * * \\
(1.043)\end{array}$ \\
\hline fmarket & $\begin{array}{l}-0.726^{* * *} \\
(0.433)\end{array}$ & $\begin{array}{l}-0.645 \\
(0.756)\end{array}$ \\
\hline DUM93-96 & $\begin{array}{l}0.255 \\
(0.917)\end{array}$ & \\
\hline DUM97-00 & $\begin{array}{l}-0.240 \\
(1.292)\end{array}$ & \\
\hline DUM01-04 & $\begin{array}{l}0.897 \\
(1.678)\end{array}$ & \\
\hline DUM $h t$ & & $\begin{array}{l}1.961 \\
(1.728)\end{array}$ \\
\hline $\begin{array}{l}\text { 2) } \mathbf{P}_{2} \mid \mathbf{P}_{3} \\
\text { constant }\end{array}$ & $\begin{array}{l}-1.190 \\
(1.171)\end{array}$ & $\begin{array}{l}0.862 \\
(0.982)\end{array}$ \\
\hline fdistance & $\begin{array}{l}1.313 * * * \\
(0.711)\end{array}$ & $\begin{array}{l}1.333 \\
(0.976)\end{array}$ \\
\hline fagglom & $\begin{array}{l}-0.756 \\
(0.661)\end{array}$ & $\begin{array}{l}-1.017 \\
(0.881)\end{array}$ \\
\hline fefficien & $\begin{array}{l}2.354 * * \\
(0.933)\end{array}$ & $\begin{array}{l}1.141 \\
(1.292)\end{array}$ \\
\hline fwisdom & $\begin{array}{l}-2.056^{* *} \\
(0.742)\end{array}$ & $\begin{array}{l}-1.562 \\
(1.157)\end{array}$ \\
\hline fmarket & $\begin{array}{l}-2.141^{*} \\
(0.810)\end{array}$ & $\begin{array}{l}-1.862 * * * \\
(1.022)\end{array}$ \\
\hline DUM93-96 & $\begin{array}{l}-1.283 \\
(1.477)\end{array}$ & \\
\hline DUM97-00 & $\begin{array}{l}0.408 \\
(1.497)\end{array}$ & \\
\hline DUM01-04 & $\begin{array}{l}3.274 * * * \\
(1.916)\end{array}$ & \\
\hline DUM $h t$ & & $\begin{array}{r}-0.124 \\
(2.035)\end{array}$ \\
\hline
\end{tabular}

\begin{tabular}{|c|c|c|}
\hline Choice of a region & Model 1 & Model 2 \\
\hline $\begin{array}{l}\text { 3) } \mathbf{P}_{4} \mid \mathbf{P}_{3} \\
\text { constant }\end{array}$ & $\begin{array}{l}-1.572 \\
(1.257)\end{array}$ & $\begin{array}{l}-1.382 \\
(1.356)\end{array}$ \\
\hline fdistance & $\begin{array}{l}0.760 \\
(0.666)\end{array}$ & $\begin{array}{l}1.329 \\
(1.118)\end{array}$ \\
\hline fagglom & $\begin{array}{l}-0.682 \\
(0.620)\end{array}$ & $\begin{array}{l}-0.679 \\
(0.966)\end{array}$ \\
\hline fefficien & $\begin{array}{l}2.205^{*} \\
(0.859)\end{array}$ & $\begin{array}{l}3.053 * * \\
(1.461)\end{array}$ \\
\hline fwisdom & $\begin{array}{l}-0.340 \\
(0.614)\end{array}$ & $\begin{array}{l}-1.505 \\
(1.237)\end{array}$ \\
\hline fmarket & $\begin{array}{l}-0.973 * * * \\
(0.546)\end{array}$ & $\begin{array}{l}-0.701 \\
(0.926)\end{array}$ \\
\hline DUM93-96 & $\begin{array}{l}0.842 \\
(1.468)\end{array}$ & \\
\hline DUM97-00 & $\begin{array}{l}2.395 \\
(1.567)\end{array}$ & \\
\hline DUM01-04 & $\begin{array}{l}1.990 \\
(2.081)\end{array}$ & \\
\hline DUMht & & $\begin{array}{l}2.944 \\
(2.074)\end{array}$ \\
\hline $\begin{array}{l}\text { 4) } \mathbf{P}_{5} \mid \mathbf{P}_{3} \\
\text { constant }\end{array}$ & $\begin{array}{l}0.997 \\
(0.829)\end{array}$ & $\begin{array}{l}0.068 \\
(0.916)\end{array}$ \\
\hline fdistance & $\begin{array}{l}0.239 \\
(0.501)\end{array}$ & $\begin{array}{l}0.701 \\
(0.862)\end{array}$ \\
\hline fagglom & $\begin{array}{l}-0.892 * * * \\
(0.538)\end{array}$ & $\begin{array}{l}-0.769 \\
(0.818)\end{array}$ \\
\hline fefficien & $\begin{array}{l}2.585^{*} \\
(0.663)\end{array}$ & $\begin{array}{l}2.885^{*} \\
(1.150)\end{array}$ \\
\hline fwisdom & $\begin{array}{l}-1.142 * * \\
(0.513)\end{array}$ & $\begin{array}{l}-1.674 * * * \\
(1.061)\end{array}$ \\
\hline fmarket & $\begin{array}{l}-0.594 \\
(0.443)\end{array}$ & $\begin{array}{l}-0.343 \\
(0.773)\end{array}$ \\
\hline DUM93-96 & $\begin{array}{l}0.863 \\
(1.001)\end{array}$ & \\
\hline DUM97-00 & $\begin{array}{l}1.001 \\
(1.304)\end{array}$ & \\
\hline DUM01-04 & $\begin{array}{l}1.423 \\
(1.715)\end{array}$ & \\
\hline DUMht & & $\begin{array}{l}3.440 * * \\
(1.781)\end{array}$ \\
\hline
\end{tabular}

${ }^{1}$ Standard errors in parentheses

$\mathbf{P}_{\mathbf{3}}$ - Mazowieckie region is the comparison group

$\mathbf{P}_{1} \mid \mathbf{P}_{\mathbf{3}}$ - North-West region vs. Mazowieckie region

$\mathbf{P}_{\mathbf{2}} \mid \mathbf{P}_{\mathbf{3}}$ - North-East region vs. Mazowieckie region

$\mathbf{P}_{\mathbf{4}} \mid \mathbf{P}_{\mathbf{3}}$ - South-East region vs. Mazowieckie region

$\mathbf{P}_{5} \mid \mathbf{P}_{\mathbf{3}}$ - South-West region vs. Mazowieckie region

$* \mathrm{p} \leq .01 * * \mathrm{p}<.05 * * * \mathrm{p}<.10$

Source: Authors' calculations using Stata 9. 
Table 7. The multinomial logit models statistics.

\begin{tabular}{l|cc}
\hline Models statistics & Model 1 & Model 2 \\
\hline & & \\
Log-Likelihood & -98.263 & -58.088 \\
Model LR $\chi 2$ & $82.938(32)^{*}$ & $39.695(24)^{* *}$ \\
Observations & 91 & 51 \\
Pseudo R & 0.297 & 0.261 \\
& & \\
\hline
\end{tabular}

$* \mathrm{p} \leq .01 * * \mathrm{p}<.05$

Source: Authors' calculations using Stata 9.

Model 1 shows the results of the estimation of the explanatory variables and time dummies used in Eq. 6 above, and it refers to the whole sample of companies. In regression 1 of that model the findings for the comparison of the choice of location between the North-West region versus the Mazowieckie region indicate that only one variable fefficien is positively significant at $1 \%$ level. This means that the North-West area, in contrast to the Mazowieckie region, is more attractive for foreign investors if low input costs as well as the availability of labour and resources are considered to be important motives for investing in Poland (hypothesis 5). The results also show that fwisdom and fmarket are statistically significant but negative at $1 \%$ and $10 \%$ level respectively. This suggests that the North-West region is less attractive than the Mazowieckie area for foreign investors for whom market-seeking and knowledge-seeking are important motives for establishing their business (hypotheses 3 and 4).

Further, the findings for the comparison of the choice between the North-East region versus the Mazowieckie region, in regression 2, show that only three of the variables used in the model turned out to be positive and statistically significant. The first two are the explanatory variables, fefficien and fdistance which are significant at 5\% and 10\% level respectively. This suggests that the probability of the inflow of FDI into the North-East area is higher than to the Mazowieckie region, if transportation costs, quality of the infrastructure, distance between the home and host country and the availability of labour at low costs are considered important motives by foreign investors (hypotheses 5 and 3). The last one is the time dummy variable DUM01-04, significant at 10\% level. This can point out that in the years closes to join the European Union (EU), the probability of investing in the North-East region is much higher then in the Mazowieckie region because this is the region which shares its borders with other countries that are going to join the EU. Similar to the above regression the results indicate that fwisdom and fmarket are statistically significant but negative. Here the significance level is different to above findings, because the former variable is significant at $5 \%$ while the latter at $1 \%$ level respectively. This may indicate that the Mazowieckie 
area is more attractive for FDI if market size and knowledge-seeking investment are of particular importance to investors (hypotheses 3 and 4).

In addition, the results in regression 3 for the comparison of the choice between the South-East region versus the Mazowieckie region are in a way similar to those in regression 1. The variable fefficien turned out to be positive and statistically significant at the $1 \%$ level. This shows that the South-East region, like the North-West, is a more attractive location for FDI than the Mazowieckie area, when labour costs and the availability of both resources and labour are important factors for investing in Poland (hypothesis 5). Conversely, the variable fmarket appeared to be statistically negative at the $10 \%$ level, indicating once again that if market factors are important motives for investing in Poland, then the Mazowieckie region is the most attractive area for the inflow of foreign capital (hypothesis 4).

Finally, the results in regression 4 for the comparison of the choice between the South-West region and the Mazowieckie region reveal that once again the predictor fefficien is positive and statistically significant at the $1 \%$ level. This demonstrates that the South-West area, like the SouthEast and North-West areas, is most desirable region to invest in compared the Mazowieckie region (hypothesis 5). In addition, out of the four available regions to investors, the South-West area seems to have the highest probability for investment associated with low input costs and the availability of resources $^{6}$. The results for the variables fagglom and fwisdom are statistically significant but negative at $10 \%$ and $5 \%$ level respectively, suggesting that the South West region is less attractive than the Mazowieckie area when agglomeration and knowledge-seeking factors are important investment motives (hypotheses 1 and 3).

In contrast to previous model, model 2 demonstrates the results of the estimation of the explanatory variables and the industry dummy used in Eq. 6 above. As shown in Table 5, this model is regressed on only 51 observations, because only this number of foreign investors in the whole sample was operating in the manufacturing sector in Poland.

In regression 1 of this model the results for the comparison of the choice of location between the North-West region versus the Mazowieckie region show that only two variables are significant. The first variable is fefficien and it is positively significant at the $1 \%$ level, indicating that the North-West area, in contrast to the Mazowieckie region, is more attractive for foreign investors from the manufacturing sector for whom labour costs and the availability of both resources and labour are important factors (hypothesis 5). The second variable is fwisdom and it is negatively significant at

\footnotetext{
${ }^{6}$ In order to obtain the odds, the coefficients $\left(\beta_{\mathrm{j} \mid \mathrm{i}}\right)$ from Table 5 needs to be $\exp \left(\beta_{\mathrm{j} \mid \mathrm{i}}\right)$.
} 
the $10 \%$ level indicating that in this case the Mazowiecie region is most preferable for those investors in manufacturing sector than the North-West area (hypothesis 3).

Additional, in regression 2 the results for the comparison of the choice between the North-East region versus the Mazowieckie region point out that only one variable fmarket is statistically significant at the $10 \%$ level and it has a negative sign. This indicates that foreign investors from the manufacturing sector prefer the Mazowieckie area as opposed to the North-East region (hypothesis 4).

Moreover, the findings in regression 3 for the comparison of the choice of location between the South-East region versus the Mazowieckie region reveal that only the variable fefficien is positively significant at $1 \%$ level. This means, that the South-East area, like the South- West and North-West areas, is more attractive place to invest in compared the Mazowiecie region (hypothesis 5). What is more, out of the three regions, the South-East area appears to have the highest probability for investors from the manufacturing sectors for whom low input costs and the availability of resources are important.

To finish, in regression 4 which compares the choice between the South-West region and the Mazowieckie region, the results demonstrate that only two variables are statistically significant and positive. The first variables is fefficien and it is significant at the $1 \%$ level, indicating that the SouthWest region is more attractive then the Mazowieckie area for manufacturing investment (hypothesis 5). The second one is the industry dummy $D U N_{h t}$ which is significant at the $5 \%$ level. This might indicate that the South-West region in relation to the Mazowieckie region is the most preferable location for foreign investors from high-tech industries. The results in this regression also show that fwisdom is negative and statistically significant at the $10 \%$ level. This shows once again that the Mazowieckie area is more attractive than the South-West region if knowledge-seeking investment even in the manufacturing sector are important factors for investing in Polish market (hypothesis 3).

The overall explanatory ability of those two models are satisfactory, as the model's statistics shows in Table 6.

\subsection{Discussion}

The results indicate that that there are substantial differences in the attractiveness of Polish regions, when the initial inflows of FDI are evaluated. 
It is shown that if input costs and the availability of labour and resources are seen by investors as important factors for investing in Poland, then all regions are more favourable for the inflow of foreign capital than the Mazowieckie area. However, the South-West region is the most preferable area for those kinds of motives. A possible explanation can be the fact that this particular region has the highest unemployment rate within the country and is rich in natural resources. The high unemployment level makes people place a higher value on their current job, with the result that they are willing to work for lower wages and perhaps show greater commitment. This could explain why Friedman et al., (1992) and Billington (1999) find that high unemployment increases FDI inflows. The availability of resources acts as an encouragement for the inflow of FDI in that region due to the fact that during the communist regime this area was "the heart" of the economy; the majority of the textile industries (the Łódź voivodship) as well as all mining production (both the Dolnośląskie and Śląskie voivodships) was based there (Churski, 2002; Dornisch, 2002).

Only one area, the North-East region, seems to be the preferable location (in comparison to the Mazowieckie area) for the inflow of FDI when geographical factors are important motives for investors. Access to the Baltic Sea and to new members of the EU, make this area very attractive for foreign capital (Nandakumar and Wagué, 2001; Górzelak, 2002). Geographical proximity and local infrastructure imply lower communication costs and fewer difficulties in managing business activities (Woodward, 1992; Hadgkinson et al., 2001; Louri et al., 2000).

If agglomeration is an important factor for investing in Poland, then the Mazowieckie area is the most attractive location for foreign investment, and more highly ranked than the North-East and South-West regions which are also considered by investors. This result is not surprising, because the centre of this region, Warsaw, is the leading area for finance, business services and real estate in Poland. As stated by Maskell and Malmberg (1999) "agglomeration of firms within a given business sector in a region will make the area especially suited to meet the specific location requirements. Even assuming that a new firm is completely free in its choice of location, the optimal location would usually be a region with a long track record of servicing firms" (p.175). Indeed, the seminal work of Wheeler and Mody (1992) makes a strong empirical case for agglomeration and market size in US investors' location decision; while Resmini and Altomonte (2001), using panel data for the period 1995-1998 to analyse the determinants of FDI inflow to Poland, find that the presence of agglomerations stimulated foreign investment into Poland. Similar conclusions were obtained by Cieślik and Ryan (2005) when using a Poisson model for the estimation of location determinants of Japanese multinationals within Poland during the period 1991-2001. 
In addition to agglomeration, the strong cultural and $R \& D$ centres of the Mazowieckie region, place this particular area as the most favourable location even if three other regions (the NorthWest, North-East and South-West) are also considered for the initial inflow of FDI. The justification can be the fact that this voivodship has the highest number of R\&D institutions and universities as well as the largest amount of expenditure devoted to R\&D by the government (Table 1).

Furthermore, the Mazowieckie region is the most attractive location for FDI when market factors are viewed as important motives, even if other regions such as the North-West, North-East and South-East are also taken into consideration by investors. This finding is hardly surprising, because the Warsaw metropolitan area is the largest market within the country (Table 1). As Vernon (1974b, 1979), Dunning (1993a), Agarwal (1980) and others have pointed out, large market size has a positive impact on the inflow of FDI.

\section{Section 4: Conclusion and policy implications}

In this paper we examined the motives for the initial inflow of foreign capital in Poland at the regional level.

We found that those investors, for whom agglomeration, knowledge and market factors are the main motives for investing in Poland, tended to choose the Mazowieckie region despite the fact that other regions were also considered. However, investors for whom low input costs, availability of labour and resources and geographical factors are significant motives for setting up a business activity in Poland, favour other regions than the Mazowieckie area. These findings confirm that Polish regions do indeed differ substantially in attracting foreign capital and that regional characteristics matter in the selection of primary location choice in Poland.

This research contributes to the literature on the determinants of spatial location of FDI in developed countries (Carlton, 1983; Friedman et al., 1992; Head et al., 1995; Coughlin et al., 1991; Louri et al., 2000; Crozet et al., 2002; Dunning, 1998); the growing literature in the same field focusing upon transition economies (Campos and Kinoshita, 2003; Mayer, 2001; Galego et al., 2004; Bevan et al., 2004). Additionally, another contribution of this research stems from the fact that this study represents one of the first attempts to test the motives of the initial inflow of foreign capital into Polish regions, using a multinomial logit model incorporating investor's specific characteristics. A final contribution of this research stems from the quantitative and cross-sectional nature of the study. 
The paper's findings suggest that the relative autonomy of Polish regions have led to differences in their attractiveness for inward foreign investment, the exploitation of regional potential, and economic development. While generally outside the scope of this paper, there are potentially significant public policy implications derived from the spatial distribution of FDI in Poland. Indeed these implications extend beyond Poland to other countries where the capital city / region is dominant in respect of levels of economic activity.

Regional policies in Poland are focused upon the creation and management of 14 Special Economic Zones (SEZs) designed to address regional imbalances. As Figure 1 shows, these SEZs are located in the regions where, for instance, efficiency-seeking FDI motives are prevalent. Hence the SEZs appear to be correctly targeted to areas of economic need. While the SEZ incentives emphasize employment creation as well as capital investment outlays through investment grants, investment incentives have been criticized as "a crude, discriminatory and expensive tool for the attraction of inward FDI" (Tavares and Young, 2005, p.4). Authors have argued instead that governments should focus upon short- and long-term measures designed to strengthen economic fundamentals and the institutional system. The local governments of those Polish regions that are least attractive to FDI would be well advised to emphasize improvements in the investment climate through political, economic and institutional reforms.

The evidence in the paper relates to FDI determinants as opposed to FDI quality. Nevertheless, there may be an assumption, for example, that where low input costs and labour availability are important motives for investment, FDI may be dominated by labour-intensive, assembly-type operations. Conversely, the importance of agglomeration and knowledge-seeking factors (as in the Mazowieckie region in Poland) may suggest higher-value added and integrated MNC operations, which in turn could further exacerbate regional inequalities in Poland. The results in this paper do not permit more refined comment on this important topic, and further research is clearly required to test the implicit hypotheses derived from the above observations.

\section{Acknowledgements}

We would like to thank three anonymous referees, John E. Jackson, Iraj Seyf, Elko Klijn for their insights and comments on previous drafts of this paper. All errors remain our own.

\section{References:}


1. Agarwal, J.P. (1980) Determinants of Foreign Direct Investment: A survey, Weltwirtschaftliches Archive, 4, 733-739.

2. Altomonte, C. (2000) Economic determinants and institutional frameworks: FDI in economies in transition. Transnational Corporations, 9/2, 75-107.

3. Bartlett, C.A. and Ghoshal, S. (1990) Managing innovation in the transnational corporation. In C.A. Bartlett, Y. Doz and G. Hedlund (eds.), Managing the global firm, London: Routledge.

4. Barrios, S. Strobl, E. and Gorg, H. (2002) Multinationals' location choice, agglomeration economies and public incentives, Nottingham University: Research Papers 33.

5. Bevan, A., Estrin, S. and Mayer, K. (2004) Foreign investment location and institutional development in transition economies, International Business Review, 13, 43-64.

6. Billington, N. (1999) The location of Foreign Direct Investment: An empirical analysis, Applied Economics, 31, 65-76.

7. Boudier-Bensebaa, F. (2005) Agglomeration economies and location choice: Foreign investment in Hungary, The Economics of Transition, 13/4, 605-629.

8. Brakman, S. and Garretsen, H. (2003) Rethinking the New Geographical Economics, Regional Studies, 37/6\& 7, 637-648.

9. Campos, N. F. and Kinoshita, Y. (2003) Why Does FDI Go Where it Goes? New Evidence from the Transition Economies, IMF Working Paper, 228, 3-31.

10. Cantwell, J.A. (1989) Technological Innovations and Multinational Corporations, London: Basil Blackwell.

11. Cantwell, J.A. and Iammarino, S. (2001) EU regions and multinational corporations: change, stability and strengthening of technological comparative advantages, Industrial and Corporate Change, 10, 1007-1037.

12. Cantwell, J.A. and Janne, O. (1999) Technological Globalisation and Innovation Centers: The Role of Corporate Technological Leadership and Locational Hierarchy, Research Policy, 28/2 \& 3, 119-144.

13. Cantwell, J.A. and Piscitello, L. (2005) Recent Location of Foreign-owned Research and Development Activities by Larger Multinational Corporations in the European Regions: The Role of Spillovers and Externalities, Regional Studies, 39/1, 1-16.

14. Cantwell, J.A. and Piscitello, L. (2002) The Location of technical activities of MNCs in European regions: The role of spillovers and local competencies, Journal of International Management, 8, 69-96.

15. Carlton, D. (1983) The Location and Employment Choices of New Firms: An econometric Model with Discrete and Continuous Endogenous Variables, Review of Economics and Statistics, 65, 440-449.

16. Chung, W. and Alcácer, J. (2002) Knowledge Seeking and Location Choice of Foreign Direct Investment in the United States, Management Science, 48/12, 1534-1554.

17. Churski, P. (2005) Problem Areas in Poland in Terms of the Objectives of the European Union's Regional Policy, European Planning Studies, 13/1, 45-72.

18. Churski, P. (2002) Unemployment and Labour-market Policy in the New Voivodship System in Poland, European Planning Studies, 10/6, 745-763.

19. Cieślik, A. and Ryan, M. (2005) Location determinants of Japanese multinationals within Poland: Do special economic zones really matter for investment decisions? Journal of Economic Integration, 20/3, 475-496.

20. Coughlin, C. and Segev, E. (2000) Locational determinants of new foreign manufacturing plants, Journal of Regional Economics, 40, 323-351. 
21. Coughlin, C.C., Terza, J.V. and Arromdee, V. (1991) State Characteristics and Location of Foreign Direct Investment within the United States, Review of Economics and Statistics, 73, 675-683.

22. Crozet, M., Mayer, T. and Mucchielli, J.L. (2002) How Do Firms Agglomerate? A Study of FDI in France, CEPR Discussion Papers 3873.

23. Culem, C.G. (1988) The Location Determinants of Direct Investment Among Industrial Countries, European Economic Review, 34/4, 885-904.

24. Czyż, T. (2002) Application of the potential model to the analysis of regional differences in Poland, Geographia Polonica, 75/1, 13-24.

25. Deichmann, J.I (2001) Distribution of Foreign Direct Investment Among Transition Economies in Central and Eastern Europe, Post-Soviet Geography and Economics, 42/2, 142-152.

26. Dillman, D. A (2000) Mail and Internet Surveys: The Tailored Design Method (2 ${ }^{\text {nd }}$ ed.), New York: John Wiley \& Sons Inc.

27. Disdier, A.C. and Mayer, T. (2004) How different is Eastern Europe? Structure and determinants of location choices by French firms in Eastern and Western Europe, Journal of Comparative Economics 32, 280-296.

28. Dornisch, D. (2002) The Evolution of Post-socialist Projects: Trajectory Shifts and Transitional Capacity in Polish Region, Regional Studies, 36/3, 307-321.

29. Dunning, J.H (1998) Location and Multinational Enterprise: A Neglected Factor? Journal of International Business Studies, 39/1, 45-65.

30. Dunning, J.H. (1993a) Multinational Enterprises and the Global Economy, Wokingham: Addison-Wesley Publishing.

31. Dunning, J.H. (1983) Changes in the level and structure of international production: the last one hundred years. In M. Casson (ed.), The Growth of International Business, London: George Allen \& Unwin.

32. Estrin, S., Bevan, A. and Meyer, K. (2001) Institution Building and the Integration of Eastern Europe in International Production, Working Paper 16, 1-37.

33. Florida, R (1997) The globalization of R\&D: Results of a survey of foreign-affiliated R\&D laboratories in the USA, Research. Policy, 26, 85-103.

34. Fujita, M., Krugman, P.R. and Venables, A.J. (1999) The Spatial Economy: Cities, Regions, and International Trade, Cambridge, MA: MIT Press.

35. Friedman, J., Gerlowski, D.A. and Silberman, J. (1992) What Attracts Foreign Multinational Corporations? Evidence from Branch Plant Location in the United States, Journal of Regional Science, 32/4, 403-418.

36. Galego, A., Vieira, C. and Vieira, I. (2004) The CEEC as FDI Attractors: A Menace to the EU Periphery? Emerging Markets Finance and Trade, 40/5, 74-95.

37. Garibaldi, P., Mora, N., Sahay, R. and Zettelmeyer, J. (2001) What Moves Capital to Transition Economies, IMF Staff Papers, 48, 109-145.

38. Ghemawat, P. and Kennedy, R.E. (1999) Competitive Shocks and Industrial Structure: The Case of Polish Manufacturing, International Journal of Industrial Organization, 17, 847-867.

39. General Statistical Office (2006) Polish Statistical Yearbook 2005, Warszawa: Zakład Wydawnictw Statystycznych.

40. General Statistical Office (2005) Polish Statistical Yearbook 2004, Warszawa: Zakład Wydawnictw Statystycznych.

41. General Statistical Office (2004) Polish Statistical Yearbook 2003, Warszawa: Zakład Wydawnictw Statystycznych.

42. General Statistical Office (2003) Polish Statistical Yearbook 2002, Warszawa: Zakład Wydawnictw Statystycznych. 
43. Górzelak, G. (2002) Polskie regiony w processie integracji europejskiej, Studia Regionalne i Lokalne, Warszawa: Wydawnictwo Naukowe Scholar.

44. Greene, W.H. (2003) Econometric Analysis, New Jersey: Pearson Education Inc.

45. Gujarati, D. N. (2003) Basic Econometrics. New York: McGraw-Hill Higher Education.

46. Hausman, J. and McFadden, D. (1984) A Specification Test for the Multinomial Logit Model, Econometrica, 52, 1219-1240.

47. Head, K.C., Ries, J.C. and Swenson, D.L. (1995) Agglomeration Benefits and Location Choice: Evidence from Japanese Manufacturing Investments in the United States, Journal of International Economics, 38, 223-247.

48. Heberlein, H.J. and Baumgartner, R (1978) Factors affecting response rates to mailed questionnaires: A quantitative analysis if the published literature, American Sociological Review, 43, 447-462.

49. Hodgkinson, A., Hyland, C. and Pomfret, S. (2001) The Determination of Location in New South Wales, Regional Studies, 35/1, 39-55.

50. Holland, D. and Pain, N. (1998) The Diffusion of Innovations In Central and Eastern Europe: A Study of The Determinants and Impact of Foreign Direct Investment, National Institute of Economic and Social Research (NIESR), 137, 6-54.

51. Jensen, C. (2004) Localized Spillovers in the Polish Food Industry: The Role of FDI in the Development Process? Regional Studies, 38/5, 535-550.

52. Jensen, C. (2000) Foreign Direct Investment and Economic Transition: Panacea or Pain Killer? CEES/INT, DK-2000, pp. 1-28.

53. Kanuk, L. and Berenson, C. (1975) Mail surveys and response rates: A literature review, Journal of Marketing Research, 14, 400-453.

54. Kogut, B. and Zandler, U. (1992) Knowledge of the firms, combinative capabilities, and the replication of technology, Organization Science, 3, 338-397.

55. Kondracki, J. (1994) Geografia Polski, Warszawa: PWN.

56. Krugman, P.R. (1998) What's New About the New Economic Geography? Oxford Review of Economic Policy, 14, 7-17.

57. Krugman, P.R. (1996) Urban Concentration: The Role of Increasing Returns and Transport Costa, International Regional Science Review, 19, 5-30.

58. Krugman, P.R. (1993) On the relationship between trade theory and location theory, Review of International Economies, 1, 102-122.

59. Krugman, P.R. (1991a) Development, Geography and Economic Theory, Cambridge, MA: MIT Press.

60. Kuemmerle, W. (1999) The Drivers of Foreign Direct Investment into Research and Development: An Empirical Investigation, Journal of International Business Studies, 30/1, 1-24.

61. Lankes, P. and Venables, A. (1996) Foreign Direct Investments in Economics of Transition: The Changing Patterns of Investments, Economics of Transition, 4, 331-347.

62. Lansbury, M., Pain, N. and Smidkowa, K. (1996a) Foreign Direct Investment in Central Europe Since 1990: An Econometric Study, National Institute Economic Review, 156, 104-113.

63. Levinson, A. (1996) Environmental regulations and manufacturer's location choices: Evidence from the Census of Manufacturers, Journal of Public Economics, 62, 5-29.

64. Long, J. S. and Freese, J. (2003) Regression Models for Categorical Dependent Variables Using Stata, Texas: Stata Press Publication.

65. Louri, H., Papanastassiou, M. and Lantouris, J. (2000) FDI in the EU periphery: A multinomial logit analysis of Greek firms strategies, Regional Studies, 34/5, 419-427.

66. Lösch, A. (1940) The Economics of location. Jena, Fischer.

67. Maddala, G.S. (1977) Econometrics, New York: McGraw-Hill Inc. 
68. Manski, Ch.F. and Lerman, S.R. (1977) The Estimation of Choice Probabilities From Choice Based Samples, Econometrica, 48/8, 1977-1988.

69. McFadden, D. (1984) Econometric Analysis of Qualitative Response Models. In Z. Grilliches and M. Intriligator (eds.), Handbook of Econometrics, Amsterdam: Academic Press.

70. Marshall, A. (1920) Principals of Economics ( $8^{\text {th }}$ ed.), London: McMillan.

71. Martin, C. and Velăzquez, F.J. (2000) Determinants of Bilateral Foreign Direct Investment Flows in the OECD with Closer Look at The Former Communist Countries. European Economy Group, Working Paper No. 2/2000.

72. Mayer, K. (2001) Institutions, Transaction Costs and Entry Mode Choice in Eastern Europe, Journal of International Business Studies, 32/2, 357-367.

73. Nandakumar, P. and Wagué, C. (2001) The Determinants of Swedish and Total Foreign Direct Investment in the Baltic, Journal of Emerging Markets, 5, 58-70.

74. Nachum, L. and Wymbs, C. (2005) Product differentiation, external economies and MNE location choices: M\&A in Global Cities, Journal of International Business Studies, 36, 415-434.

75. Oerlemans, L.A.G. and Meeus, M H. (2005) Do Organisational and Spatial Proximity Impact on Firms performance? Regional Studies, 39/1, 89-104.

76. Polish Information and Foreign Investment Agency (2004) Yearbook 2003, Warsaw.

77. Polish Information and Foreign Investment Agency (2003) Yearbook 2002, Warsaw.

78. Porter, M. (2003) The Economic Performance of Regions, Regional Studies, 37/6\&7, 549-578.

79. Przybylska, K. and Malina, A. (2000) The Determinants of Foreign Direct Investment in Transforming Economies: Empirical Evidence from Poland, Statistics in Transition. 4/5, 883899.

80. Pusterla, F. and Resmini, L. (2005) Where do foreign firms locate in transition countries? An empirical investigation, Centre for Research on Latin American Studies and Transition Economies (LSLA), Working Paper.

81. Resmini, L. (2007) Regional Patterns of Industry Location in Transition Countries: Does Economic Integration with the EU Matter? Regional Studies, 41/6, 747-764.

82. Resmini, L. (2003) Economic integration, industry location and frontier economies in transition countries, Economic Studies, 27,205-221.

83. Rasmini, L. (2000) The Determinants of Foreign Direct Investment into the CEECs: New Evidence from Sectoral Panel, The Economics of Transition, 8/3, 665-689.

84. Resmini, L. and Altomonte, C. (2001) Multinational Corporations as Catalyst for Industrial Development: The Case of Poland, Milan and LICOS Centre for Transition Economies, Working Paper No. 368.

85. Shaver, J.M. (1998) Do Foreign-Owned and U.S.-Owned Establishments Exhibit the Same Location Pattern in U.S. Manufacturing Industries? Journal of International Business Studies, 29/3,469-492.

86. Sley, B. (2003) Eastern European Investment Summit: From disparity towards integration, New York: International Herald Tribune, 9, 1.

87. Sounders, M., Lewis, P. and Thornhill, A. (2000) Research Methods for Business Studies (2 ed.), Essex: Pearson Education.

88. The Economist Intelligence Unit (2004) Country Profile: Poland, London.

89. The Economist Intelligence Unit (2003) Country Profile: Poland, London.

90. Tavares, A.T. and Young, S. (2005) FDI and Multinationals: Patterns, Impacts and Policies, International Journal of the Economics of Business, Special Issue, 12/1, 3-17.

91. Wang, Z.Q. and Swain, N. (1995) The Determinants of Foreign Direct Investment in Transforming Economies: Empirical Evidence for Hungary and China, Weltwirtschaftliches Archive, 132/2, 359-382. 
92. Weber, A. (1909) Theory of the Location of Industries, Chicago: University of Chicago Press.

93. Willits, F.K. and Saltiel, J. (1995) Question order effects on subjective measures of quality of life, Rural Sociology, 60, 654-665.

94. Woodward, D.P. (1992) Location Determinants of Japanese Manufacturing Start-ups in the United States, Southern Economic Journal, 58, 690-708.

95. Wheeler, D. and Mody, A. (1992) International Investment Location Decisions: The Case of U.S. Firms, Journal of International Economics, 33/1\&2, 57-76.

96. Vernon, R. (1979) The Product Cycle hypothesis in a New International Environment, Oxford Bulletin of Economics and Statistics, 41, 255-67.

97. Vernon, R. (1974b) The Location of Economic Activity. In J.H. Dunning, (ed.), Economic Analysis and the Multinational Enterprises, London.

\section{Appendix}

Table 8: Sample characteristics

\begin{tabular}{|l|c|c|c|c|}
\hline & USA & EU & OTHES & TOTAL \\
\hline Investment type & Freq. $(\%)$ & Freq. $(\%)$ & Freq. $(\%)$ & Freq. $(\%)$ \\
\hline Greenfield & & & & \\
\hline Joint Ventures & $\mathbf{4}(33.33)$ & $\mathbf{1 8}(25.35)$ & $\mathbf{3}(37.50)$ & $\mathbf{2 5}(27.47)$ \\
\hline M\&A & $\mathbf{4}(33.33)$ & $\mathbf{2 8}(39.44)$ & $\mathbf{5}(62.50)$ & $\mathbf{3 7}(40.66)$ \\
\hline & $\mathbf{4}(33.33)$ & $\mathbf{2 5}(35.21)$ & $\mathbf{0}(0.00)$ & $\mathbf{2 9}(31.87)$ \\
\hline Sector of economic activity & & & & \\
\hline Industry & & & & \\
\hline Agriculture, hunting and forestry & $\mathbf{7}(58.33)$ & $\mathbf{4 1}(57.75)$ & $\mathbf{3}(37.50)$ & $\mathbf{5 1}(56.04)$ \\
\hline Construction & $\mathbf{1}(8.33)$ & $\mathbf{2}(2.82)$ & $\mathbf{0}(0.00)$ & $\mathbf{3}(3.30)$ \\
\hline Trade and repair & $\mathbf{1}(8.33)$ & $\mathbf{1 1}(15.49)$ & $\mathbf{1}(12.50)$ & $\mathbf{1 3}(14.29)$ \\
\hline Hotels and restaurants & $\mathbf{0}(0.00)$ & $\mathbf{2}(2.82)$ & $\mathbf{1}(12.50)$ & $\mathbf{3}(3.30)$ \\
\hline Transport, storage intermediation & $\mathbf{0}(0.00)$ & $\mathbf{2}(2.82)$ & $\mathbf{1}(12.50)$ & $\mathbf{3}(3.30)$ \\
\hline Other services & $\mathbf{0}(0.00)$ & $\mathbf{3}(4.23)$ & $\mathbf{0}(0.00)$ & $\mathbf{3}(3.30)$ \\
\hline & $\mathbf{3}(25.00)$ & $\mathbf{1 0}(14.08)$ & $\mathbf{2}(25.00)$ & $\mathbf{1 5}(16.48)$ \\
\hline MNC's no of employees in Poland & & & & \\
\hline $50-149$ & & & & \\
\hline $150-249$ & $\mathbf{0}(0.00)$ & $\mathbf{1}(1.41)$ & $\mathbf{0}(0.00)$ & $\mathbf{1}(1 . .10)$ \\
\hline $250-349$ & $\mathbf{0}(0.00)$ & $\mathbf{2}(2.82)$ & $\mathbf{0}(0.00)$ & $\mathbf{2}(2.20)$ \\
\hline $350-449$ & $\mathbf{0}(0.00)$ & $\mathbf{1}(1.41)$ & $\mathbf{1}(12.50)$ & $\mathbf{2}(2.20)$ \\
\hline $450-549$ & $\mathbf{2}(16.67)$ & $\mathbf{5}(7.04)$ & $\mathbf{0}(0.00)$ & $\mathbf{7}(7.69)$ \\
\hline More than 550 & $\mathbf{4}(33.33)$ & $\mathbf{1 6}(22.54)$ & $\mathbf{2}(25.00)$ & $\mathbf{2 2}(24.18)$ \\
\hline & $\mathbf{6}(50.00)$ & $\mathbf{4 6}(64.79)$ & $\mathbf{5}(62.50)$ & $\mathbf{5 7}(62.64)$ \\
\hline MNC's size (domestic and foreign employment) & & & & \\
\hline $850-1049$ & & & & \\
\hline $1049-1249$ & $\mathbf{1}(8.33)$ & $\mathbf{3}(4.23)$ & $\mathbf{0}(0.00)$ & $\mathbf{4}(4.40)$ \\
\hline $1250-1449$ & $\mathbf{0}(0.00)$ & $\mathbf{1}(1.41)$ & $\mathbf{0}(0.00)$ & $\mathbf{1}(1.10)$ \\
\hline More than 1450 & $\mathbf{3}(25.00)$ & $\mathbf{1 0}(14.08)$ & $\mathbf{1}(12.50)$ & $\mathbf{1 4}(15.38)$ \\
\hline & $\mathbf{8}(66.67)$ & $\mathbf{5 7}(80.28)$ & $\mathbf{7}(97.50)$ & $\mathbf{7 2}(79.12)$ \\
\hline TOTAL & & & & \\
\hline Source: Authors & $\mathbf{1 2}(100)$ & $\mathbf{7 1}(100)$ & $\mathbf{8}(100)$ & $\mathbf{9 1}(100)$ \\
\hline
\end{tabular}

Source: Authors calculations using Stata 9. 
Figure 2 Distribution of foreign investors in the data sample.

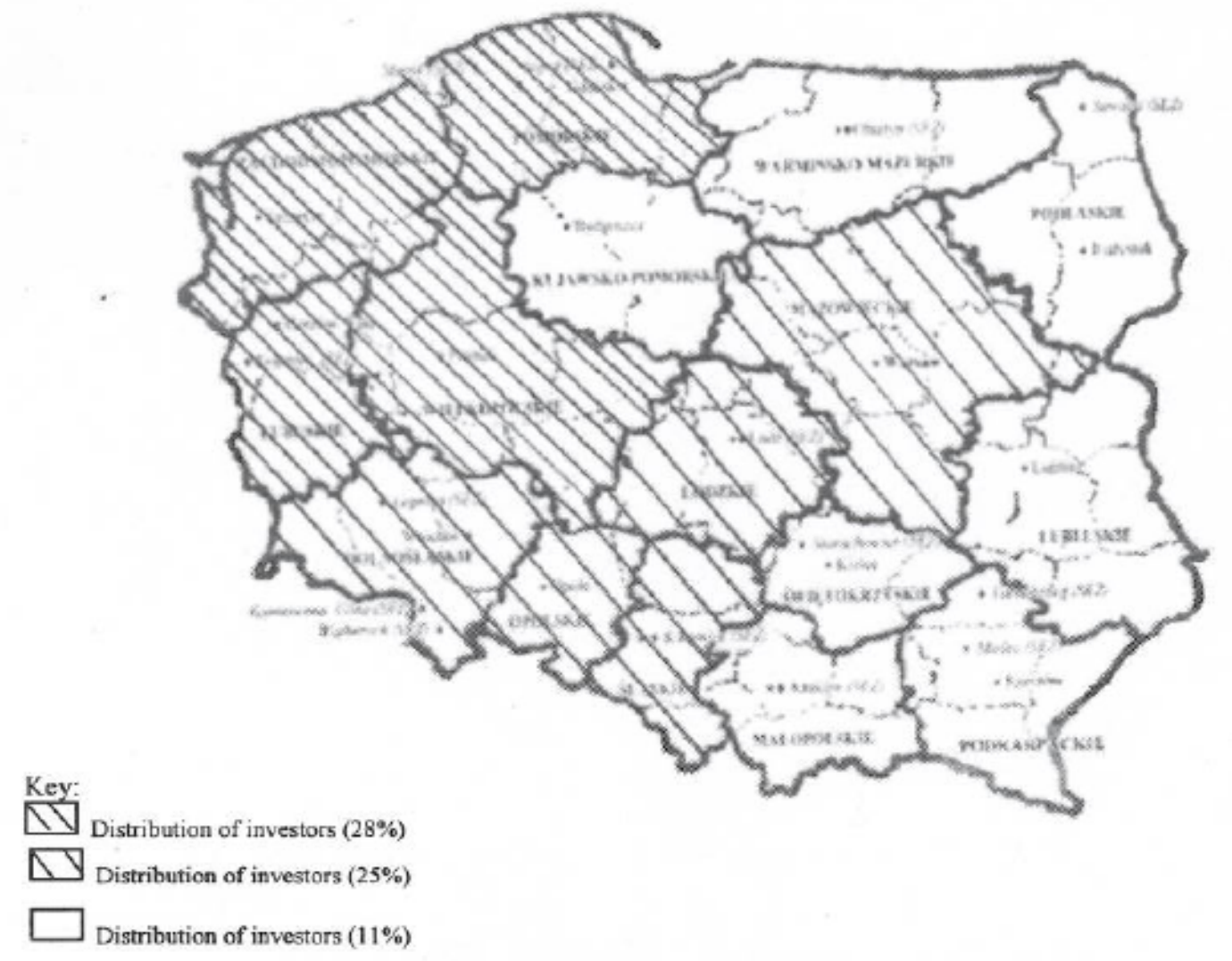




\section{DAVIDSON INSTITUTE WORKING PAPER SERIES - Most Recent Papers}

The entire Working Paper Series may be downloaded free of charge at: www.wdi.umich.edu

CURRENT AS OF 12/8/08

\begin{tabular}{|c|c|c|}
\hline Publication & Authors & Date \\
\hline No. 943: Regional Determinants of FDI Distribution in Poland & $\begin{array}{l}\text { Agnieszka Chidlow and Stephen } \\
\text { Young }\end{array}$ & Nov 2008 \\
\hline No. 942: Structural Reform and Firm Exports & $\begin{array}{l}\text { Alvaro Cuervo-Cazurra \& Luis } \\
\text { Alfonso Dau }\end{array}$ & Sept 2008 \\
\hline $\begin{array}{l}\text { No. 941: Exploring The Relationship Between Military Spending \& Human } \\
\text { Rights Performance In South Asia }\end{array}$ & $\begin{array}{l}\text { Krishna Chaitanya, Vadlamannati } \\
\text { and K K Shakya Lahiru Pathmalal }\end{array}$ & Oct 2008 \\
\hline $\begin{array}{l}\text { No. 940: Structural Reform And Firm Profitability In Developing } \\
\text { Countries }\end{array}$ & $\begin{array}{l}\text { Alvaro Cuervo-Cazurra \& Luis } \\
\text { Alfonso Dau }\end{array}$ & July 2008 \\
\hline $\begin{array}{l}\text { No. 939: Does Timing Of Elections Instigate Riots? } \\
\text { A Subnational Study Of } 16 \text { Indian States, } 1958 \text { - } 2004\end{array}$ & Krishna Chaitanya Vadlamannati & Oct 2008 \\
\hline $\begin{array}{l}\text { No. 938: Price Setting And Market Structure: An Empirical Analysis Of } \\
\text { Micro Data }\end{array}$ & Fabrizio Coricelli \& Roman Horvath & Sept 2008 \\
\hline $\begin{array}{l}\text { No. 937: Inflation Differentials in EU New Member States: An Empirical } \\
\text { Evidence }\end{array}$ & Roman Horvath \& Kamila Koprnicka & Oct 2008 \\
\hline $\begin{array}{l}\text { No. 936: Market Reforms and Growth in Post-socialist Economies: } \\
\text { Evidence from Panel Cointegration and Equilibrium Correction Model }\end{array}$ & Igor Pelipas and Alexander Chubrik & Sept 2008 \\
\hline $\begin{array}{l}\text { No. 935: Derivatives trading and the volume-volatility link in the Indian } \\
\text { Stock Market }\end{array}$ & $\begin{array}{l}\text { S. Bhaumiky, M. Karanasosy and } \\
\text { A. Kartsaklas }\end{array}$ & April 2008 \\
\hline $\begin{array}{l}\text { No. 934: Yuan Real Exchange Rate Undervaluation, 1997-2006. How } \\
\text { Much, How Often? Not Much, Not Often }\end{array}$ & $\begin{array}{l}\text { Jeff Chen, Wende Deng \& David } \\
\text { Kemme }\end{array}$ & Aug 2008 \\
\hline $\begin{array}{l}\text { No. 933: How Important Are Foreign Shocks in Small Open Economy? } \\
\text { The Case of Slovakia }\end{array}$ & $\begin{array}{l}\text { Roman Horváth and Marek } \\
\text { Rusnák }\end{array}$ & Sept 2008 \\
\hline $\begin{array}{l}\text { No. 932: Estimating Poverty for Indigenous Groups in Chile } \\
\text { by Matching Census and Survey Data }\end{array}$ & $\begin{array}{l}\text { Claudio A. Agostini, Philip H. } \\
\text { Brown, and Andrei Roman }\end{array}$ & Aug 2008 \\
\hline $\begin{array}{l}\text { No. 931: Is There Electoral Cycles In Globalization Process? Evidence } \\
\text { From } 78 \text { Democratic Countries, } 1975 \text { - } 2006\end{array}$ & Krishna Chaitanya Vadlamannati & Sept 2008 \\
\hline No. 930: Lobbying, Corruption \& Other Banes & $\begin{array}{l}\text { Nauro Campos \& Francesco } \\
\text { Giovannoni }\end{array}$ & Sept 2008 \\
\hline $\begin{array}{l}\text { No. 929: Do Elections Slow Down Economic Globalization Process In } \\
\text { India? It's Politics Stupid! }\end{array}$ & Krishna C Vadlamannati & Aug 2008 \\
\hline $\begin{array}{l}\text { No. 928: Impact Of Institutional Quality On Human Rights Abuses } \\
\text { In Transition Economies }\end{array}$ & $\begin{array}{l}\text { Krishna C Vadlamannati \& Artur } \\
\text { Tamazian }\end{array}$ & July 2008 \\
\hline $\begin{array}{l}\text { No. 927: Do Choice \& Speed Of Reforms Matter For } \\
\text { Human Rights During Transition? }\end{array}$ & Krishna Chaitanya Vadlamannati & July 2008 \\
\hline $\begin{array}{l}\text { No. 926: Socioeconomic, Institutional \& Political Determinants Of } \\
\text { Human Rights Abuses: A Subnational Study Of India, } 1993 \text { - } 2002\end{array}$ & Krishna Chaitanya Vadlamannati & July 2008 \\
\hline $\begin{array}{l}\text { No. 925: Does the Entry Mode of Foreign Banks Matter for Bank } \\
\text { Efficiency? Evidence from the Czech Republic, Hungary, and } \\
\text { Poland }\end{array}$ & $\begin{array}{l}\text { Ngoc-Anh Vo Thi \& Dev } \\
\text { Vencappa }\end{array}$ & July 2008 \\
\hline No. 924: Impact Of Economic Reforms On Poverty - Indian Experience & Krishna Chaitanya Vadlamannati & July 2008 \\
\hline $\begin{array}{l}\text { No. 923: India \& South Asia - Indian Economic Reforms \& Direct } \\
\text { Foreign Investments: How Much Difference Do They Make To } \\
\text { Neighbors? }\end{array}$ & Krishna Chaitanya Vadlamannati & July 2008 \\
\hline $\begin{array}{l}\text { No. 922: The Effects of Monetary Policy in the Czech Republic: } \\
\text { An Empirical Study }\end{array}$ & $\begin{array}{l}\text { Magdalena Morgese Borys and } \\
\text { Roman Horváth }\end{array}$ & May 2008 \\
\hline $\begin{array}{l}\text { No. 921: Goods Market Integration in Russia during the Economic } \\
\text { Upturn }\end{array}$ & Konstantin Gluschenko & May 2008 \\
\hline $\begin{array}{l}\text { No. 920: Labour Market Matching Efficiency In The Czech Republic } \\
\text { Transition }\end{array}$ & Pablo de Pedraza & April 2008 \\
\hline
\end{tabular}

